\title{
UPAYA MENCIPATAKAN MEDIA MASSA DAKWAH (Sebuah Kajian Teoantroposentris)
}

\author{
Abd Hadi Faishol \\ STAI Miftahul Ulum Pamekasan \\ Email: hadifaishol84@gmail.com \\ Muhammad Ahnu Idris \\ STAI Miftahul Ulum Pamekasan \\ Email: putra.nusantarasta63@gmail.com
}

\begin{abstract}
This paper discusses the inculcation of religious values in the mass media, so that the news is preaching and can be an intermediary to build a society that is in accordance with the guidance of Islamic law. With qualitative analysis, the results of this paper are elaborated in the form of a translation based on existing literature and data based on the Theoantropocentric Theory. Media actors as a profession have taken shortcuts by referring to the principle of benefits prioritizing the principle of benefits in their coverage and reporting, which is at the same time paradoxical to the professional ethics they carry. Compounded by the lack of respect for the principle of presumption of innocence in the name of the public interest in obtaining information, will increasingly make mass media and media actors as dominant individuals in reconstructing and manipulating social reality.
\end{abstract}

Keyword: Teoantroposentris, media massa, dakwah.

\section{Pendahuluan}

Sebagai basis masyarakat (the basic of society), dalam kenyataan proses komunikasi antarmanusia terjadi dalam beberapa konteks atau level. Sehubungan dalam prosesnya tercakup banyak aspek interpersonal: kelompok, publik dan komunikasi organisasi, yaitu level mass (massa). ${ }^{1}$ Dalam aplikasinya, komunikasi dalam konteks massa tersebut, menurut Littlejohn (dalam Imran: 2012), biasanya dilakukan dengan memanfaatkan media. Terkait dengan pemanfaatannya, maka ada yang melalui media elektronik (televisi, radio), cetak (suratkabar, majalah, buletin dll.) dan belakangan ada yang melalui media online. ${ }^{2}$

\footnotetext{
${ }^{1}$ Hasyim Ali Imran, “ Media Massa, Khalayak Media, The Audience Theory, Efek Isi Media Dan Fenomena Diskursif (Sebuah Tinjauan dengan Kasus pada Surat kabar Rakyat Merdeka)", Jurnal Studi Komunikasi dan Media, Vol. 16, No. 1 (Januari-Juni, 2012), 47.

${ }^{2}$ Ibid, 48.
} 
Pada era informasi ini, lingkungan hidup masyarakat tidak lepas dari pengaruh media massa. Anak-anak, remaja serta orang tua hampir setiap hari mendapatkan exposure (terpaan) berbagai media massa. Terpaan media massa yang dilakukan secara terus menerus ini akan memberikan dampak terhadap kehidupan. Oleh karena itu, menanamkan nilai-nilai agama perlu kerjasama semua pihak, termasuk media massa. Exposure media massa perlu memberikan contoh nyata dalam rangka membentuk pribadi yang sesuai dengan nilai-nilai agama. ${ }^{3}$ Maka dari itu, untuk mencapai tujuan tersebut membangun media massa yang memprioritaskan nilai-nilai agama dan menjunjung etika menjadi salah satu alternatif.

3 Oos M. Anwas, "Membangun Media Massa Publik Dalam Menanamkan Pendidikan Karakter", Jurnal Pendidikan dan Kebudayaan, Vol. 17, No. 6 (Nopember, 2011), 682. 


\section{Paradigma Teoantroposentris dalam Islam}

Alquran dan hadith merupakan wahyu dari Allah yang diturunkan kepada Muhammad SAW. yang di dalamnya berisi aturan-aturan tentang kehidupan manusia. Kedua pedoman itu diturunkan sebagai petunjuk etika, kebijaksanaan, dan dapat menjadi grand theory. ${ }^{4}$ Teoantroposentrisme mengklaim bahwa agama sebagai sumber kebenaran, etika, hukum kebijaksanaan dan sedikit pengetahuan, namun bukan satu-satunya. Ada sumber pengetahuan yang lain yang berasal dari manusia. ${ }^{5}$

Teori antroposentris merupakan suatu teori yang menyinergikan antara nilai-nilai ketuhanan dan akal. ${ }^{6}$ Artinya, teori ini mengakui perpaduan antara dua sumber pengetahuan: pengetahuan ilahiah dan pengetahuan insani. ${ }^{7}$ Atau dengan kata lain, keilmuan yang positivistik-sekularistik telah disesuaikan dengan kepribadian Islam. $^{8}$ Kuntowijoyo (dalam Zainiyati: 2015) menggambarkan alur pertumbuhan ilmu-ilmu integralistik sebagai berikut: Agama $\rightarrow$ teoantropesntrisme $\rightarrow$ dediferensiasi $\rightarrow$ ilmu integralistik. ${ }^{9}$ Bagan ini dapat dijelaskan sebagai berikut adalah:

a. Agama. Agama Islam, yang seluruh ajarannya bersumber dari Alquran, merupakan wahyu Tuhan yang mengatur hubungan manusia denganNya, diri sendiri, lingkungan (fisik, sosial, budaya). Alquran merupakan petunjuk etika, kebijaksanaan dan, dalam konteks ini, dapat dijadikan sebagai grand theory. Wahyu tidak pernah mengklaim sebagai ilmu qua ilmu;

b. Teoantroposentrisme. Agama memang mengklaim sebagai sumber kebenaran, etika, hukum, kebijaksanaan. Agama tidak hanya menjadikan wahyu Tuhan sebagai satu-satunya sumber pengetahuan dan melupakan kecerdasan manusia, atau sebaliknya menganggap pikiran manusia sebagai satu-satuya sumber pengetahuan dan melupakan Tuhan. Jadi sumber

\footnotetext{
${ }^{4}$ Hasan Bisyri, "Mengakhiri Dikotomi Ilmu Dalam Dunia Pendidikan", Forum Tarbiyah, Vol. 7, No. 2 (Desember, 2009), 191.

${ }^{5}$ Ibid.

'Supawi Pawenang, “Genealogi Sekularisme Pada Ilmu Manajemen”, Subuf, Vol. 23, No, 1 (Mei, 2011), 66 .

${ }^{7}$ Ali Ahmad Yenuri, "Problema Aktivitas Pembelajaran”, Miyah, Vol. X, No. 1 (Januari, 2015), 97. Lihat juga: Alim Ruswantoro, "Epistemologi Pemikiran Islam M. Amin Abdullah", dalam Islam, Agama-Agama, dan Nilai Kemanusiaan: Festschrift Untuk. M. Amin Abdullah, ed. Moch Nur Ichwan, et al, (Yogyakarta: CISForm (Center for the Study of Islam and Social Transformation) UIN Sunan Kalijaga Yogyakarta, 2013), 21.

${ }^{8}$ Kamaluddin, "Dakwah dan Pengembangan Masyarakat Islam (Konsep Dasar dan Arah Pengembangan)", Hikmah, Vol. VIII, N0. 2 (Juli, 2014), 51.

${ }^{9}$ Husniyatus Salamah Zainiyati, "Landasan Fondasional Integrasi Keilmuan di UNI Maulana Malik Ibrahim Malang dan UIN Sunan Ampel Surabaya", Islamica: Jurnal Studi Keislaman, Vol. 10, No. 1 (Spetember, 2015), 262.
} 
pengetahuan ada dua macam, yaitu yang berasal dari Tuhan dan yang berasal dari manusia;

c. Dediferensiasi. Peradaban yang disebut Pascamodern/Post-modern perlu ada perubahan. Perubahan itu adalah dediferensiasi. Kalau diferensiasi menghendaki pemisahan antara agama dan sektor-sektor kehidupan lain, maka dediferensiasi adalah penyatuan kembali agama dengan sektorsektor kehidupan lain, termasuk agama dan ilmu;

d. Ilmu integralistik. Ilmu yang menyatukan wahyu Tuhan dan temuan pikiran manusia. Ilmu-ilmu integralistik tidak akan mengucilkan Tuhan (sekularisme) atau mengucilkan manusia. Diharapkan integralisme akan sekaligus menyelesaikan konflik antara sekularisme ekstrem dan agamaagama radikal dalam banyak sektor. ${ }^{10}$

Berdasarkan penjelasan bagan tersebut, jelas sekali bahwa titik pijak teori ini adalah filsafat Islam, yang dalam tradisinya senantiasa memadukan antara akal dan wahyu, kemudian secara otomatis membentuk dediferensiasi dan melahirkan ilmu yang integralistik. Penempatan filsafat Islam sebagai basis konstruksi ilmu didasarkan pada pemahaman bahwa induk semua ilmu adalah filsafat, dan khazanah keilmuan Islam sudah semestinya menjadikan filsafat Islam sebagai basis kajian ontologisnya. ${ }^{11}$ Dediferensiasi ialah penyatuan kembali agama dengan sektor-sektor kehidupan lain, termasuk agama dan ilmu. Bila disebutkan hasil penyatuan agama dan wahyu sebagai ilmu-ilmu integralistik (sebagai suatu paradigma baru, paradigma Islam), maka kalau disandingkan urutan logis dari ilmu-ilmu Barat (sekularistik) dan ilmu-ilmu Islam, masing-masing akan nampak sebagai berikut: ${ }^{2}$

Paradigma Islam:

Ilmu Barat (Modern) dan Ilmu Islam (Pascamodern)

\begin{tabular}{|c|c|c|l|c|c|}
\hline & $\begin{array}{c}\text { Period } \\
\mathbf{e}\end{array}$ & $\begin{array}{c}\text { Sumbe } \\
\mathbf{r}\end{array}$ & Etika & $\begin{array}{c}\text { Proses } \\
\text { Sejarah }\end{array}$ & Ilmu \\
\hline $\begin{array}{c}\text { Bara } \\
\mathbf{t}\end{array}$ & $\begin{array}{c}\text { Moder } \\
\mathrm{n}\end{array}$ & Akal & Humanisme & Diferensiasi & $\begin{array}{c}\text { Sekular, } \\
\text { Otonom }\end{array}$ \\
\hline $\begin{array}{c}\text { Isla } \\
\mathbf{m}\end{array}$ & $\begin{array}{c}\text { Pasca } \\
\text { Moder } \\
\mathrm{n}\end{array}$ & $\begin{array}{c}\text { Wahyu- } \\
\text { akal }\end{array}$ & $\begin{array}{c}\text { Humanisme } \\
\text {-teosentris }\end{array}$ & $\begin{array}{c}\text { Dediferensia } \\
\text { si }\end{array}$ & $\begin{array}{c}\text { Integralisti } \\
\mathrm{k}\end{array}$ \\
\hline
\end{tabular}

\footnotetext{
${ }^{10}$ Ibid, 262-263.

11 M. Zainal Abidin, "Filsafat Ilmu-Ilmu Keislaman Integralistik: Studi Pemikiran Kuntowijoyo", Ilmu Ushuluddin, Vol. 13, No. 2 (Juli, 2014), 129.

12 Anshori et al., "Format Baru Hubungan Sains Modern Dan Islam (Studi Integrasi Keilmuan Atas UIN Yogyakarta Dan Tiga Uinversitas Islam Swasta Sebagai Upaya Membangun Sains Islam Seutuhnya Tahun 2007-2013)", (Laporan Penelitian-Universitas Muhammadiyah Surakarta, Surakara, 2013), 14-15.
} 
Teoantroposentris menegaskan bahwa agama menjadi tolok ukur kebenaran ilmu (benar, salah), bagaimana ilmu diproduksi (baik, buruk), dan tujuan-tujuan ilmu (manfaat, merugikan). Dengan kata lain, manusia hanya memiliki hak untuk memikirkan dinamika internal ilmu sehingga menjadi ilmu yang obyektif. Meskipun ilmu integralistik lahir dari agama, namun menjadi gejala keilmuan yang obyektif yang dirasakan sebagai gejala keilmuan bukan norma oleh pemeluk agama lain, non-agama dan anti-agama. ${ }^{13}$

Kuntowijoyo (dalam Thoib dan Mukhlis: 2013) meyakini bahwa wahyu memiliki signifikansi dalam membangun keilmuan yang integralistik dan menghilangkan pandangan yang dikotomis tentang bidang-bidang ilmu. Paradigma ini dinilai memiliki prospek yang kuat dalam melahirkan konsepkonsep dan temuan-temuan keilmuan yang relevan dengan realitas dan kebutuhan umat, serta dalam memecahkan setiap persoalan kemanusiaan dan dalam upaya menjaga eksistensi alam dan seisinya. Prospek ini akan semakin optimal, apabila terus dibangun kolaborasi yang integral antara tiga macam ayat Tuhan (qawliyyah, kawniyyah, insaniyyah). Konsepsi paradigma keilmuan Islam yang integralistik, yang ditawarkan Kuntowijoyo ini, telah memperlebar peta pemikiran intelektual Muslim dalam upaya mengembangan ilmu di dunia Islam, sekaligus merupakan bantahan terhadap kritikan yang menolak penggunaan Alquran di luar kajian ilmu-ilmu agama. ${ }^{14}$

Paradigma keilmuan, oleh karena itu, tidak mempertentangkan antara wahyu dan pikiran manusia, mestinya yang menyatukan antara keduanya. Maksud penyatuan tersebut adalah keduanya sebenarnya merupakan satukesatuan yang 'tak terpisahkan sebagaimana dua sisi mata uang, dan penyatuan ini tidak akan berakibat mengecilkan peran Tuhan (sekularisme) atau mengucilkan manusia sehingga teralienasi dari dirinya sendiri, dari masyarakat sekitarnya, dan lingkungan hidup sekitarnya. Dari konsep penyatuan ini -atau katakan integrasi-interkoneksi atau reintegrasi-reinterkoneksi keilmuan sekaligus- akan dapat mengakhiri konflik sekularisme ekstrim dengan fundamentalisme negatif agama-agama yang rigid dan radikal dalam banyak hal. ${ }^{15}$ Artinya, memposisikan wahyu (baca: Alquran) sebagai paradigma berarti memberikan porsi terhadap Alquran, sebagaimana dipahami Thomas Kuhn (dalam Mujahidin: 2013), sebagai suatu konstruksi pengetahuan yang memungkinkan umat Islam memahami realitas sebagaimana berlandaskan Alquran. Kemudian konstruksi pengetahuan tersebut menjadi dasar perumusan grand desaign mengenai sistem Islam termasuk sistem ilmu pengetahuannya.

\footnotetext{
${ }^{13}$ Anwar Mujahidin, "Epistemologi Islam: Kedudukan Wahyu Sebagai Sumber Ilmu”, Ulumuna: Jurnal Studi Keislaman, Vol. 17, No. 1 (Juni, 2013), 49.

14 Ismail Thoib dan Mukhlis, "Dari islamisasi Ilmu Menuju Pengilmuan Islam: Melawan Hegemoni Epistemologi Barat”, Ulumuna: Jurnal Studi Keislaman, Vol. 17, No.1 (Juni, 2013), 89.

${ }^{15}$ Ruswantoro, "Epistemologi Pemikiran", 21.
} 
Dengan demikian paradigma Alquran tidak hanya berhenti pada kerangka aksiologis tetapi juga dapat berfungsi memberi kerangka epistemologis. ${ }^{16}$

Secara singkat, teori teoantroposentris dapat diartikan menjadikan Tuhan sebagai asal dan tujuan dari segala proses ilmiah tanpa meninggalkan peran manusia sebagai makhluk yang memiliki mandat ilmiah. ${ }^{17}$ Pendekatan ini menekankan bahwa di atas segala upaya dan pengetahuan manusia ada Dzat Yang Maha Mengetahui yaitu Tuhan Yang Maha Esa. ${ }^{18}$ Semangat penyatuan kembali antara agama dan ilmu dalam gagasan teoantroposentris ini memunculkan gagasan pengembangan filsafat ilmu keislaman yang integratif dengan ilmu-ilmu lainnya. ${ }^{19}$

\section{Genealogi Media Massa}

Istilah media massa biasanya merujuk pada penyebaran informasi melalui buku, surat kabar, majalah, film, radio, program-program televisi, CD, DVD, dan sebagainya. Straubhaar dan LaRose (dalam Dalyono: 2010) menekankan pada saluran (channe) yang digunakan yakni: cetak seperti buku, majalah, tabloid, surat kabar; dan elektronik seperti radio, televisi, dan film yang sering disebut sebagai "old media". ${ }^{20}$ Sejalan dengan perkembangan jaman, saat ini terdapat beraneka-ragam media yang memberikan informasi dengan karakteristiknya masing-masing. Setiap karakteristik yang berbeda ini akan berbeda pula dalam proses penyampaian pesannya. ${ }^{21}$

Senada dengan pernyataan di atas Joseph Turow (Dalyono: 2010) menyatakan bahwa media massa adalah instrumen teknologi komunikasi massa yakni "the industrialized production and multiple distribution of messages through technological devices". Konvergensi antara media massa, komputer, dan telekomunikasi berujung pada internet yakni "a network of networks that connects computers worldwide..." yang akhirnya melahirkan sebuah masyarakat informasi. ${ }^{22}$ Selain itu, media massa juga diartikan sebagai media komunikasi dan informasi yang melakukan penyebaran informasi secara massal dan dapat diakses oleh

\footnotetext{
${ }^{16}$ Mujahidin, "Epistemologi Islam, 49-50.

${ }^{17}$ Imam Taufiq, "Komitmen Kebangsaan IAIN", Suara Merdeka (7 April 2014), 6.

${ }_{18}$ Mamluatul Inayah, "Konsep Ihsan Sebagai Pendidikan Karakter Dalam Pemikiran Schiko Murata dan William C. Chittick (Tesis-Universitas Negeri Maulana Malik Ibrahim, Malang, 2015), 76.

${ }^{19}$ Ruswantoro, "Epistemologi Pemikiran", 22.

${ }^{20}$ C. Teguh Dalyono, "Pengaruh Media Massa Dan Pengetahuan Tentang Teknologi Informasi Terhadap Pemanfaatan Teknologi Informasi Dan Tingkat Modernitas Generasi Muda Kota Yogyakarta”, Jurnal Ilmu Komunikasi, Vol. 8, No.1 (Januari-April, 2010), 89.

${ }^{21}$ Fuad Abbas Saleh Pasallo, "Peran Media Massa Cetak (Koran) Dalam Meningkatkan Pariwisata Danau Dua Rassa (Labuan Cermin), Berau”, eJournal Ilmu Komunikasi, Vol. 1, No. 4 (tanpa bulan, 2013), 91.

${ }^{22}$ Dalyono, "Pengaruh Media", 89
} 
masyarakat secara massal pula. Informasi massa adalah informasi yang diperuntuktukkan kepada masyarakat secara massal, bukan informasi yang hanya boleh dikonsumsi oleh pribadi. ${ }^{23}$

Dari pemaparan di atas, dapat tergambar karakteristik media massa sebagaimana dikemukakan oleh Asep Saiful Muhtadi (dalam Syobah: 2013): pertama, komunikasi massa berlangsung satu arah; kedua, komunikasinya bersifat melembaga; ketiga, pesan-pesan yang disampaikan bersifat umum; keempat, pesan-pesan yang disampaikan lewat media digunakan secara serempak; kelima, komunikannya bersifat heterogen. ${ }^{24}$ Berkembangnya teknologi, semakin mempermudah masyarakat dalam memperoleh informasi, dimana mobilitas masyarakat yang tinggi, tidak terlepas dengan kegiatan komunikasi, yang saling memberi dan menerima informasi. Bagi sebagian anggota masyarakat, saat ini informasi sudah merupakan kebutuhan, maka masyarakat selalu mencari informasi dari berbagai media massa dimana saja dan kapan saja. ${ }^{25}$ Sebagai media komunikasi massa, media massa berfungsi sebagai: sumber informasi, hiburan, persuasi, transmisi budaya, mendorong kohesi sosial, pengawasan, korelasi, pewarisan sosial, melawan kekuasaan dan kekuatan represif. Fungsi ini dapat dijelaskan sebagai berikut:

a. Fungsi Informasi

Menyampaikan informasi secara cepat kepada khalayak merupakan fungsi pokok komunikasi massa. Melalui media massa yang digunakan, informasi yang telah dikumpulkan dan dikemas kemudian disebarluaskan kepada khalayak luas.

b. Fungsi Hiburan

Hiburan juga merupakan salah satu fungsi lain media massa. Sebagaimana diketahui, unsur hiburan ini paling nyata dan menonjol dalam media massa terdapat pada media TV jika dibandingkan dengan media massa lainnya. Apalagi untuk TV swasta, proporsi acara atau tayangan yang bernuansa hiburan sangatlah menonjol. Namun demikian, masih ada kombinasi dengan fungsi-fungsi lainnya seperti penyampaian informasi, dll.

c. Fungsi Persuasi

Persuasi sebagai salah satu fungsi komunikasi massa yakni kemampuan media massa dalam memengaruhi khalayaknya agar berbuat sesuatu sesuai apa yang ditawarkan media massa yang bersangkutan. Contoh: tajuk rencana, artikel, surat pembaca adalah bernuansa persuasif. Persuasi bisa datang dalam berbagai bentuk: (1) mengukuhkan atau memperkuat sikap, kepercayaan, atau nilai seseorang; (2) mengubah sikap, kepercayaan, atau

\footnotetext{
${ }^{23}$ Pasallo, "Peran Media", 92.

${ }^{24}$ Nurul Syobah, "Konstruksi Media Massa Dalam Pengembangan Dakwah", Jurnal Dakwah Tabligh, Vol. 14, No.2 (Desember, 2013), 159

${ }^{25}$ Ibid, 91-92.
} 
nilai seseorang; (3) menggerakkan seseorang untuk melakukan sesuatu; dan (4) memperkenalkan etika, atau menawarkan nilai tertentu.

d. Fungsi Transmisi Budaya

Terjadinya perubahan ataupun pergeseran budaya atau nilai-nilai budaya dalam suatu masyarakat, tidak terlepas dari keberhasilan media massa dalam memperkenalkan budaya-budaya global kepada audiens. Hal ini juga seiring dengan perkembangan teknologi informasi dan komunikasi yang merambah ke berbagai area kehidupan masyarakat, termasuk budaya.

e. Fungsi untuk Mendorong Kohesi Sosial

Kohesi sama dengan penyatuan. Kohesi sosial sebagai salah satu fungsi komunikasi massa, maksudnya media massa ikut berperan dalam mendorong masyarakat agar bersatu. Misalnya: ketika media massa memberitakan tentang pentingnya kerukunan antar umat beragama, secara tidak langsung media tersebut berfungsi mewujudkan terjadinya kesatuan secara sosial bagi masyarakat.

f. Fungsi Pengawasan

Fungsi pengawasan yang dilakukan oleh media massa adalah mengontrol aktivitas masyarakat secara keseluruhan. Pengawasan dapat dilakukan media massa dalam bentuk kontrol sosial, peringatan, dan atau persuasif. Contohnya: pemberitaan tentang terorisme di Indonesia merupakan salah satu bukti peringatan kepada khalayak akan bahaya dan ancaman terorisme. Pemberitaan tentang kasus mafia peradilan juga merupakan salah satu contoh kontrol sosial yang dilakukan media massa.

g. Fungsi Korelasi

Maksudnya, media massa berfungsi menghubungkan berbagai elemen masyarakat. Misalnya peran media masssa sebagai jembatan penghubung masyarakat dengan pemerintah terkait dengan kebijakan-kebijakan yang tidak berpihak (merugikan) masyarakat.

h. Fungsi Pewarisan Sosial

Pada konteks fungsi pewarisan sosial, media massa diibaratkan seperti seorang 'pendidik' yang berusaha meneruskan atau menurunkan ilmu pengetahuan, nilai-nilai, norma, dogma, bahkan etika kepada khalayaknya.

i. Fungsi Melawan Kekuasaan dan Kekuatan Represif

Media massa selain dapat dijadikan alat merebut dan mempertahankan kekuasaan, juga bisa dipakai untuk melawan dan merobohkan kekuasaan. Contohnya: tumbangnya rezim Orde Baru, tidak terlepas dari pengaruh media massa yang ikut memberitakan dan melakukan investigasi. Media massa tidak lagi sekadar meneruskan perkataan-perkataan pejabat 
pemerintah, tetapi ikut membongkar kasus ketidak-adilan yang dilakukan pemerintah. $^{26}$

Berdasarkan pemaparan di atas, media massa memiliki andil yang sangat signifikan dalam mengkonstruksi suatu 'tatanan baru' di masyarakat. Sering tidak disadari oleh khalayak bahwa realitas yang disampaikan media massa berbeda dengan realitas yang sesungguhnya terjadi. Lewat teks berita yang didengar dan dibacanya, seseorang digiring untuk memahami realitas yang telah dibingkai oleh media massa. Pemahamannya terhadap realitas tergantung pada realitas pola media massa. Ia telah terperangkap oleh pola konstruksi media massa. ${ }^{27}$ Dengan demikian, media massa harus diisi oleh pribadi-pribadi yang memang betul-betul menjunjung tinggi nilai-nilai agama.

\section{Teoantroposentris sebagai upproach media massa Dakwah}

Tidak diragukan lagi, media massa memiliki peran penting dalam mengkonstruksi realitas di masyarakat, maka dari itu tidak heran jika kemudian media massa dimanfaatkan oleh banyak kepentingan baik kepentingan ekonomi, politik dan kepentingan lainnya. ${ }^{28}$ Pada perkembangan institusi media di Indonesia, aspek kepemilikan saham di media (kepemimpinan), ekonomi dan pemasaran media sangat menentukan ideologi yang diusung media, di mana ideologi tersebut jika mengarah pada pendekatan ekonomi politik media akan memunculkan pelaku media yang kurang akrab dengan etika komunikasi. Etika komunikasi di sini ditempatkan hanya sebagai instrumen belaka dan menjadi kurang bermakna dalam menentukan isi program, kualitas program serta penghormatan pelaku media terhadap hak asasi manusia yang direpresentasikan pada individu sebagai sumber informasi. Pilihan ini menimbulkan etika komunikasi pada pelaku media dianggap sudah mengalami reduksi. Pelaku media sebagai profesi telah mengambil jalan pintas dengan mengacu asas manfaat lebih mengutamakan asas manfaat dalam peliputan dan pemberitaannya, yang sekaligus paradoks dengan etika profesi yang diembannya. ${ }^{29}$

1. Teoantroposentris di Media Massa

Teoantroposentris di media berarti menanamkan nilai-nilai ketuhanan pada media (massa). Nilai-nilai ketuahanan ini bertujuan supaya media massa yang ada saat ini tidak hanya berorientasi profit belaka, tapi juga

\footnotetext{
${ }^{26}$ Fatma Laili Khoirun Nida, "Persuasi Dalam Media Komunikasi Massa", At-Tabsyir: Jurnal Komunikasi Penyiaran Islam, Vol. 2, No.2 (Juli-Desember, 2014), 87-89.

${ }^{27}$ Masnur Muslich, "Kekuasaan Media Massa Mengonstruksi Realitas", Babasa dan Seni, Tahun 63, No. 2 (Agustus, 2008), 150.

${ }^{28}$ Sy. Nurul Syobah, "Peran Media Massa Dalam Komunikasi Politik", Jurnal Komunikasi Sosial dan Keagamaan, Vol. XV, No. 1 (Juni, 2012), 15.

${ }^{29}$ Abdul Choliq Dahlan, "Hukum, Profesi Jurnalistik dan Etika Media Massa", Jurnal Hukum, Vol. XXV, No. 1 (April, 2011), 395.
} 
menjadikan media tersebut ideal dan menjunjung tinggi etika penyiaran sesuai dengan ajaran agama.

Etika penyiaran menjadi suatu hal yang urgen dalam situasi negeri yang seperti saat ini. Harapannya adalah media massa tetap berpegang pada kaidah-kaidah etika pemberitaan sehingga dapat menjalankan fungsi imperatifnya secara optimal, yakni menyediakan informasi yang dibutuhkan oleh masyarakat dan mencerahkan. Tinjauan etika religius dapat diterapkan dalam melihat penerapan etika pemberitaan oleh karena aspek religius menjadi sumber nilai dalam tradisi keagamaan yang dalam konteks masyarakat turut membangun dan menyumbangkan nilai-nilai yang diterima oleh masyarakat itu sendiri. ${ }^{30}$

Water Lippman (dalam Rachman: 2013) menjelaskan tentang lingkungan semu (pseudo-environment). Ia mengatakan bahwa dunia objektif yang dihadapi manusia itu " "tak terjangkau, "tak terlihat, dan 'tak terbayangkan." Oleh sebab itulah manusia membangun sendiri dunia yang ada di pikirannya dalam upaya sedikit memahami dunia objektif tersebut. Dari sinilah kemudian media memainkan perannya yang dapat mempercepat, memperkuat dan melekatkan dunia semu sehingga menambah jarak antara manusia modern dengan dunia nyata. Berdasarkan uraian ini dapat dipahami bahwa ternyata media komunikasi dan penyiaran sangat lekat dengan masyarakat. Dengan kedua hal tersebut bisa memengaruhi perilaku dan budaya masyarakat di suatu wilayah. Dan jika tidak ada etika yang dibarengi dengan landasan agama dalam penyiaran di Indonesia tidak menutup kemungkinan akan merusak citra dan moral bangsa. ${ }^{31}$

Sebagai agama dakwah Islam mewajibkan umatnya melakukan internalisasi, transmisi, difusi, transformasi, dan aktualisasi nilai-nilai (baca: syari'at) Islam dengan metode dan media yang bersumber dari Alquran, sebagai kitab dakwah, dan sunnah Rasulullah kepada mad'u (umat manusia). Hal ini sebagai bentuk ikhtiar Muslim untuk membuat syariaat Islam menjadi kenyataan dalam kehidupan individu, keluarga, komunitas, dan khalayak secara berjamaah sehingga terwujud umat baik yang berkehidupan baik di dunia kini dan baik di akhirat kelak. ${ }^{32}$

Dakwah memiliki dua dimensi: pertama, penyampaian pesan kebenaran yang isinya mengenai dimensi kerisalahan; kedua mencakup pengaplikasian nilai kebenaran yang merupakan dimensi kerahmatan. Dalam perspektif agama, dakwah mewajibkan umatnya melakukan internalisasi,

${ }^{30}$ Joko Tri Haryanto, "Etika Islam Tentang Pemberitaan Politik di Indonesia", Yudisia, Vol. 6, No. 1 (Juni, 2015), 49.

31 Abdul Rachman, "Etika Penyiaran Dalam Perspektif Islam", Risalah, Vol. XXIV, Edisi 2 (November, 2013), 29.

32 Ibid, 32 . 
transmisi, difusi, transformasi, dan aktualisasi syariat Islam dengan metode dan media yang bersumber pada Alquran, sebagai kitab dakwah, dan sunnah Rasulullah kepada mad'u (umat manusia). Dengan begitu dapat sesuai dengan landasan syariat Islam yaitu sebagaimana Allah amanatkan dalam QS. AlFurqan: "Dan hamba-bamba yang baik dari Tuban Yang Maha Penyayang itu ialah orang-orang yang berjalan di atas bumi dengan rendah hati dan apabila orang-orang bodoh menyapa mereka, mereka mengucapkan kata-kata yang mengandung keselamatan". Maka berdasarkan ayat ini sudah sepantasnya siaran acara televisi dan film-film layar lebar tidak mengandung pengaruh kerusakan moral seperti SARA, mistis, kekerasan, dan lain-lainnya yang jauh dari kebaikan. Efek besar dari sebuah film yang dikatakan oleh Soelarko (dalam Rachman: 2013) adalah peniruan yang diakibatkan oleh anggapan bahwa apa yang dilihatnya wajar dan pantas dilakukan oleh setiap orang. Agama Islam sudah mengatur masalah penyiaran lewat kaidah-kaidah dakwah. Pernyataan ini dapat dilihat dalam surah Q.S Ali-Imran ayat 20: "Maka sesunggubnya kewvajibanmu banyalah menyampaikan" dan surah Q.S An-Nahl ayat 82: "Maka apabila mereka berpaling (juga), sesunggubnya kewajibanmu banyalah menyampaikan yang terang dan nyata". Dan ketika seseorang sudah menyampaikan sesuatu kepada sesama manusia, maka akan ada hukuman jika yang disampaikannya tidak sesuai dengan kenyataan dan pastinya tidak sesuai dengan syariat Islam, yaitu sebagaimana yang disampaikan Allah pada surah Q.S Ar-Ra'ad ayat 40: "Maka sampaikan dan kewajiban-Ku adalah membuat perbitungan". Dalam ayat ini Allah menyerukan umat-Nya supaya menyampaikan segala sesuatu berita dan informasi dengan kejujuran dan sesuai dengan fakta yang ada tanpa ada rekayasa sedikitpun, dan Allah akan melakukan perhitungan atas apa yang manusia sampaikan kepada umat lain di dunia. ${ }^{33}$

Media massa pada hakekatnya adalah suatu okupasi (lapangan pekerjaan) yang berkualifikasi dan menuntut syarat keahlian tinggi kepada para pengemban dan pelaksananya. Orang-orang di dalamnya dituntut memiliki kepekaan sosial yang tinggi, dengan memberikan kontribusi positif dari peliputan dan pemberitaannya. Hal ini sudah barang tentu tidak dapat dilepaskan dari fungsi media massa sebagai institusi di mana wartawan sebagai fungsi pendidikan, penyebar informasi dan menghibur. ${ }^{34}$ Akan tetapi tidak jarang dinamisme komersial menjadi kekuatan dominan penentu makna pesan dan keindahan (estetika). Logika pasar mengarahkan pengorganisasian sistem informasi yang disampaikan oleh media. Banyak pimpinan media yang berasal dari dunia perusahaan mau membenarkan logika pasar itu. Seakan

33 Ibid.

${ }^{34}$ Dahlan, "Hukum, Profesi”, 41-42.. 
kompetensi jurnalisme hanya merupakan faktor produksi yang fungsi pertamanya adalah menopang kepentingan pasar. ${ }^{35}$

Realitas pasar ini menggambarkan betapa media massa berada di bawah tekanan ekonomi persaingan yang keras dan ketat. Hukum persaingan menuntut media massa bisa menampilkan informasi terbaru, tidak didahului oleh media lain. "Slow news, no news" yang menjadi slogan CNN adalah ilustrasi kerasnya tuntutan persaingan antara media. Hanya dengan mempertahankan aktualitas, keuntungan ekonomi bisa diperoleh. Keuntungan ini yang akan menjamin keberlangsungan sebuah media. Aktual, cepat dan ringkas mendefinisikan logika waktu pendek. Pragmatisme ekonomi memaksa media mengadopsi mentah-mentah logika waktu pendek (memburu deadline). Logika ini menuntut pengorganisasian kerja harus tepat waktu, ringkas dan menguntungkan. Logika yang sama juga menciptakan anggapan bahwa informasi yang baik adalah bila didapatkan secara langsung, peliputan langsung, siaran langsung, reportase ke tempat kejadian dan informasi dari sumber pertama. ${ }^{36}$

2. Prinsip Dasar Etika Media Massa

Dua kutub aliran besar filsafat moral yaitu Etika Deontologi (deontological ethics) dan Etika Teleologi (teleological ethics). Vivian (dalam Haryanto: 2015) secara berbeda memberi penekanan pada basis etikanya yakni pada proses dan satunya lagi pada hasil. Bagi Aliran Deontology, masyarakat dipandang telah berlaku secara moral kalau masyarakat mengikuti aturan dengan baik. Sementara itu, Etika Teleologi menekankan aspek etika ini pada hasil perbuatan. Pada masa sekarang ini pandangan etika dengan pendekatan etika deontologi ataupun etika teleologi secara murni sudah banyak ditinggalkan orang. Para etikawan berusaha mengadakan sintesis kedua pendekatan etika ini guna mendapatkan rumusan etika yang dipandang paling sesuai dengan perkembangan dan kepentingan masyarakat umum. Berikut ini penulis kutip pendapat Haryanto bekenaan tentang berapa prinsip yang cukup memberi gambaran bagaimana media massa seharusnya menentukan sikapnya dalam aktivitas jurnalistiknya. ${ }^{37}$

a. Konsep The Golden Mean Aristoteles menunjuk moral virtue is appropriate location between two extrems. Titik kunci dari ide etika ini adalah kebaikan moral yang berada di antara dua ekstrim, menghindari sikap ekstrim menuju moderasi dan seimbang (moderation and balance). Dalam jurnalisme modern, prinsip ini ditemukan dalam konsep balance and fairness (seimbang dan kejujuran):

\footnotetext{
35 Ibid, 400.

${ }^{36}$ Ibid.

${ }^{37}$ Haryanto, "Etika Islam", 55-57.
} 
b. Imperatif kategori (categorical imperative) yang dinyatakan sebagai act on the maxim that you would want to become universal law. Semua orang seharusnya bertindak sesuai dengan aturan yang dipahami merupakan diyakini sebagai hukum universal. Imperatif kategoris ini tidak menyuruh untuk jujur atau menghindari bohong karena pertimbangan tertentu, tetapi karena jujur itu sudah dari "sono"nya baik dan bohong itu sendiri memang suatu yang salah. Media massa sudah semestinya memahami kaidah-kaidah yang berlaku secara universal ini sehingga tidak melakukan pelanggaran terhadap masyarakat;

c. Etika situasi (Situation Ethics) yang sebenarnya bentuk sanggahan terhadap imperatif kategoris Kant. Dalam pandangan etika ini, norma moral tidak berlaku universal melainkan relatif karena setiap situasi memiliki keadaan yang berbeda. Semangat dari etika ini adalah media massa dan para jurnalis tidak boleh melanggar hukum yang berlaku dan melakukan praktek yang membahayakan kepentingan masyarakat, tetapi ia harus menghormati pandangan-pandang yang berlaku dalam masyarakat tersebut;

d. Etika Utilitarian (utilitarian ethics) dari Jeremy Bentham yang dikembangkan lebih lanjut oleh John Stuart Mill yakni konsep the greatest happiness of the greatest number, kebahagiaan yang paling besar dari jumlah yang paling banyak. Inti gagasan ini sebenarnya adalah ada perbedaan kualitatif instrinsik pelbagai macam kesenangan, bahwa beberapa jenis kesenangan lebih bernilai dan diinginkan dibanding kesenangan yang lain tanpa harus bertentangan dengan prinsip manfaat. Dalam konteks media massa prinsip ini diterapkan dalam konsep jurnalisme the people's right to know, hak masyarakat untuk tahu, dan hak mendapatkan informasi;

e. Etika Tanggung jawab Sosial (Social Responsibility Etbics) yang konsep ini dimunculkan dalam Komisi Hutchins (dipimpin oleh Robert M. Hutchins) suatu komisi yang dibentuk oleh masyarakat profesional jurnalis di Amerika Serikat tahun 1947. Komisi Hutchin ini merekomendasikan media massa dan para jurnalis untuk melakukan aktivitasnya sebagai bagian dari pelayanan terhadap tanggung jawab sosialnya.

Hal inilah yang mendorong munculnya forum wartawan dan masyarakat -dalam Committee of Concerned Jurnalists - merumuskan prinsipprinsip jurnalisme agar aktivitasnya tetap pada koridor tujuan utama jurnalisme dalam menyediakan informasi yang diperlukan orang agar bebas dan bisa mengatur diri sendiri. Prinsip-prinsip yang disusun oleh Kovach tersebut antara lain: Kewajiban pertama jurnalisme adalah pada kebenaran, Loyalitas kepada masyarakat, disiplin verifikasi, menjaga independensi terhadap sumber berita, menjadi pemantau kekuasaan, menyediakan forum kritik maupun dukungan masyarakat, berupaya keras untuk membuat hal 
yang penting menarik dan relevan, menyiarkan berita komprehensif dan proporsional, serta diperbolehkan mengikuti nurani mereka. ${ }^{38}$

Prinsip-prinsip tersebut sesuai dengan firman Allah dalam Q.S AnNahl ayat 125: "Serulah Tubanmu dengan bikmah, dan nasehat yang baik, dan bertukar fikiranlah dengan cara yang lebih baik. Sesungguhnya Tubanmu lebih mengetahui siapa yang sesat dari jalan-Nya, dan Dialah yang mengetabui siapa yang terpimpin". Maka atas dasar ayat tersebut para pelaku media harus dapat menyiarkan dan mengkomunikasikan segala sesuatunya sesuai kemampuan diri dengan menjadikan dakwah suatu proses memengaruhi tingkah laku, pemikiran dan juga kehidupan orang lain sesuai dengan ajaran Islam. Etika dalam penyiaran di Indonesia sudah seharusnya bisa dilihat dan dimasukkan sesuai dengan nilai-nilai agama dalam kegiatan penyiaran. ${ }^{39}$

Terhambatnya proses penghormatan atas etika pada profesi jurnalistik dan institusi media merupakan akibat desakralisasi terhadap pemaknaan profesi dan profesionalisme tersebut justru akan semakin menjauhkan cita-cita suatu negara untuk mewujudkan tata tentram kerta raharja. Banyak dari aspek-aspek terpenting dari aturan masyarakat untuk sebagian besar bergantung pada berfungsinya profesi-profesi dengan baik. Kegiatan jurnalistik dan pemberian informasi secara jujur kepada masyarakat luas dilaksanakan dalam suatu konteks profesional. Dalam aturan dan tatanan masyarakat modern, terjalin erat hasil dari berfungsinya profesi-profesi. Profesi-profesi dalam sistem sosial okupasi (pekerjaan) menempati kedudukan yang sangat strategis. Profesi-profesi dan profesionalisme banyak dibicarakan orang tidak hanya terbatas pada soal pengertiannya, melainkan juga telah meliputi soal fungsinya dalam perkembangan masyarakat industrial yang modern.

\section{A. Penutup}

Kepemilikan saham di media (kepemimpinan), ekonomi dan pemasaran media akan sangat menentukan ideologi yang diusung media, di mana ideologi tersebut jika mengarah pada pendekatan ekonomi politik media akan memunculkan pelaku media yang kurang akrab dengan etika komunikasi. Etika komunikasi di sini ditempatkan hanya sebagai instrumen belaka dan menjadi kurang bermakna dalam menentukan isi program, kualitas program serta penghormatan pelaku media terhadap hak asasi manusia yang direpresentasikan pada individu sebagai sumber informasi. Pilihan ini menimbulkan etika komunikasi pada pelaku media dianggap sudah mengalami reduksi.

\footnotetext{
38 Ibid, 57.

${ }^{39}$ Rachman, “Etika Penyiaran”, 33.
} 
Pelaku media sebagai profesi telah mengambil jalan pintas dengan mengacu asas manfaat lebih mengutamakan asas manfaat dalam peliputan dan pemberitaannya, yang sekaligus paradoks dengan etika profesi yang diembannya. Diperparah lagi ketiadaan penghormatan atas asas praduga tak bersalah atas nama demi kepentingan publik untuk memperoleh informasi, akan semakin menjadikan media massa dan pelaku media sebagai pribadipribadi yang dominan dalam merekonstruksi dan memanipulasi realitas sosial.

Hingga di sini pilihan terhadap kecenderungan pemaknaan pendekatan ekonomi politik atau pendekatan etika, sebenranya keduanya tidak memiliki implikasi hukum yang kentara, semuanya dikembalikan kepada masing-masing pribadi yang terlibat dalam aktivitas di institusi media massa.

\section{DAFTAR PUSTAKA}

Abidin, M. Zainal. "Filsafat Ilmu-Ilmu Keislaman Integralistik: Studi Pemikiran Kuntowijoyo". Ilmu Ushuluddin. Vol. 13, No. 2. Juli, 2014.

Anshori et. al. "Format Baru Hubungan Sains Modern Dan Islam (Studi Integrasi Keilmuan Atas UIN Yogyakarta Dan Tiga Uinversitas Islam Swasta Sebagai Upaya Membangun Sains Islam Seutuhnya Tahun 20072013)". Laporan Penelitian-Universitas Muhammadiyah Surakarta, Surakara, 2013.

Anwas, Oos M. "Membangun Media Massa Publik Dalam Menanamkan Pendidikan Karakter". Jurnal Pendidikan dan Kebudayaan. Vol. 17, No. 6. Nopember, 2011.

Bisyri, Hasan. "Mengakhiri Dikotomi Ilmu Dalam Dunia Pendidikan". Forum Tarbiyah. Vol. 7, No. 2. Desember, 2009.

Dahlan, Abdul Choliq. "Hukum, Profesi Jurnalistik dan Etika Media Massa". Jurnal Hukum. Vol. XXV, No. 1. April, 2011.

Dalyono, C. Teguh. "Pengaruh Media Massa Dan Pengetahuan Tentang Teknologi Informasi Terhadap Pemanfaatan Teknologi Informasi Dan Tingkat Modernitas Generasi Muda Kota Yogyakarta”. Jurnal Ilmu Komunikasi. Vol. 8, No.1. Januari-April, 2010.

Haryanto, Joko Tri. "Etika Islam Tentang Pemberitaan Politik di Indonesia". Yudisia. Vol. 6, No. 1. Juni, 2015.

Imran, Hasyim Ali. “ Media Massa, Khalayak Media, The Audience Theory, Efek Isi Media Dan Fenomena Diskursif (Sebuah Tinjauan dengan Kasus 
pada Surat kabar Rakyat Merdeka)". Jurnal Studi Komunikasi dan Media, Vol. 16, No. 1. Januari-Juni, 2012.

Inayah, Mamluatul. "Konsep Ihsan Sebagai Pendidikan Karakter Dalam Pemikiran Schiko Murata dan William C. Chittick. Tesis-Universitas Negeri Maulana Malik Ibrahim, Malang, 2015.

Kamaluddin. "Dakwah dan Pengembangan Masyarakat Islam (Konsep Dasar dan Arah Pengembangan)". Hikmah. Vol. VIII, N0. 2. Juli, 2014.

Mujahidin, Anwar. "Epistemologi Islam: Kedudukan Wahyu Sebagai Sumber Ilmu". Ulumuna: Jurnal Studi Keislaman. Vol. 17, No. 1. Juni, 2013.

Muslich, Masnur. "Kekuasaan Media Massa Mengonstruksi Realitas". Bahasa dan Seni. Tahun 63, No. 2. Agustus, 2008.

Nida, Fatma Laili Khoirun. "Persuasi Dalam Media Komunikasi Massa". AtTabsyir: Jurnal Komunikasi Penyiaran Islam. Vol. 2, No.2. Juli-Desember, 2014.

Pasallo, Fuad Abbas Saleh. "Peran Media Massa Cetak (Koran) Dalam Meningkatkan Pariwisata Danau Dua Rassa (Labuan Cermin), Berau". eJournal Ilmu Komunikasi. Vol. 1, No. 4. tanpa bulan, 2013.

Pawenang, Supawi. “Genealogi Sekularisme Pada Ilmu Manajemen”. Subuf. Vol. 23, No, 1. Mei, 2011.

Rachman, Abdul. "Etika Penyiaran Dalam Perspektif Islam". Risalah. Vol. XXIV, Edisi 2. November, 2013.

Ruswantoro, Alim. "Epistemologi Pemikiran Islam M. Amin Abdullah". dalam Islam, Agama-Agama, dan Nilai Kemanusiaan: Festschrift Untuk M. Amin Abdullah. ed. Moch Nur Ichwan, et al. Yogyakarta: CISForm (Center for the Study of Islam and Social Transformation) UIN Sunan Kalijaga Yogyakarta, 2013.

Syobah, Nurul. "Konstruksi Media Massa Dalam Pengembangan Dakwah". Jurnal Dakwah Tabligh. Vol. 14, No.2. Desember, 2013.

Syobah, Sy. Nurul. "Peran Media Massa Dalam Komunikasi Politik". Jurnal Komunikasi Sosial dan Keagamaan. Vol. XV, No. 1. Juni, 2012.

Taufiq, Imam. "Komitmen Kebangsaan IAIN”. Suara Merdeka. 7 April 2014.

Thoib, Ismail dan Mukhlis. "Dari islamisasi Ilmu Menuju Pengilmuan Islam: Melawan Hegemoni Epistemologi Barat". Ulumuna: Jurnal Studi Keislaman. Vol. 17, No.1. Juni, 2013. 
Yenuri, Ali Ahmad. "Problema Aktivitas Pembelajaran”. Miyah, Vol. X, No. 1. Januari, 2015.

Zainiyati, Husniyatus Salamah. "Landasan Fondasional Integrasi Keilmuan di UNI Maulana Malik Ibrahim Malang dan UIN Sunan Ampel Surabaya". Islamica: Jurnal Studi Keislaman. Vol. 10, No. 1. Spetember, 2015. 